\title{
Organochloride pesticides induced hepatic ABCG5/G8 expression and lipogenesis in Chinese patients with gallstone disease
}

\author{
Guixiang $\mathrm{Ji}^{1,4, *}$, Cheng $\mathrm{Xu}^{2,3, *}$, Haidong Sun ${ }^{5, *}$, Qian Liu ${ }^{2,3}$, Hai Hu${ }^{1}$, Aihua Gu ${ }^{2,3}$ and \\ Zhao-Yan Jiang ${ }^{1}$ \\ 1 Department of Hepatobiliary and Pancreatic Surgery, Center of Gallbladder Disease, Shanghai East Hospital, Tongji \\ University School of Medicine, Shanghai, China \\ ${ }^{2}$ State Key Laboratory of Reproductive Medicine, Institute of Toxicology, Nanjing Medical University, Nanjing, China \\ ${ }^{3}$ Key Laboratory of Modern Toxicology of Ministry of Education, School of Public Health, Nanjing Medical University, Nanjing, \\ China \\ ${ }^{4}$ Nanjing Institute of Environmental Sciences/Key Laboratory of Pesticide Environmental Assessment and Pollution Control, \\ Ministry of Environmental Protection, Nanjing, China \\ ${ }^{5}$ Department of Surgery, Shanghai Institute of Digestive Surgery, Ruijin Hospital, Shanghai Jiao Tong University School of \\ Medicine, Shanghai, China \\ * These authors have contributed equally to this study and all should be considered as first authors \\ Correspondence to: Aihua Gu, email: aihuagu@njmu.edu.cn
}

Zhao-Yan Jiang, email: zhaoyanjiang@gmail.com

Keywords: gallstone disease; organochlorine pesticides; adipose tissue; liver; lipogenesis; Pathology Section

Received: April 01,2016 Accepted: April 27, $2016 \quad$ Published: May 17, 2016

\section{ABSTRACT}

Background: Organochlorine pesticides (OCPs) are one kind of persistent organic pollutants. Although they are reported to be associated with metabolic disorders, the underlying mechanism is unclear. We explored the association of OCPs with gallstone disease and its influence on hepatic lipid metabolism.

Materials and Methods: OCPs levels in omentum adipose tissues from patients with and without gallstone disease between 2008 and 2011 were measured by GC-MS. Differences of gene expression involved in hepatic lipid metabolism and hepatic lipids content were compared in liver biopsies between groups with high and low level of OCPs. Using HepG2 cell lines, the influence on hepatic lipid metabolism by individual OCP was evaluated in vitro.

Results: In all patients who were from non-occupational population, there were high levels of $\beta$-hexachlorocyclohexane $(\beta-H C H)$ and $p^{\prime}, p^{\prime}$-dichloroethylene $\left(p^{\prime}, p^{\prime}-D D E\right)$ accumulated in adipose tissues. Both $\beta-H C H$ and $p^{\prime}, p^{\prime}-$ DDE levels were significantly higher in adipose tissues from patients with gallstone disease (294.3 \pm 313.5 and $2222 \pm 2279 \mathrm{ng} / \mathrm{g}$ of lipid) than gallstone-free controls (282.7 4449.0 and $2025 \pm 2664 \mathrm{ng} / \mathrm{g}$ of lipid, $P<0.01$ ) and they were strongly related with gallstone disease ( $P$ for trend $=\mathbf{0 . 0 0 0 4}$ and $\mathbf{0 . 0 1 3 8}$ ). Furthermore, higher OCPs in adipose tissue led to increase in the expression of hepatic cholesterol transporters ABCG5 and G8 $(+34 \%$ and $+27 \%, P<0.01)$ and higher cholesterol saturation index in gallbladder bile, and induced hepatic fatty acids synthesis, which was further confirmed in HepG2 cells.

Conclusion: OCPs might enhance hepatic secretion of cholesterol into bile via ABCG5/G8 which promoting gallstone disease as well as lipogenesis. 


\section{BACKGROUND}

Organochlorine pesticides (OCPs) is one kind of persistent organic pollutants (POPs) that have been worldwide used in agricultural control of pests historically. Although OCPs are banned for agricultural use during the 70s and 80s last century, they still can be detected in water [1] or fat-containing foods such as fish, milk and meat [2]. They are characterized as high lipophilic and persistent in the environment, which are toxic to human health. They can be biomagnified in the food chain [3] and accumulate in the adipose tissues for many years. OCPs have prolonged half-life of years to decades and are resistant to degradation [4]. Consequentially, they can lead to long-term toxicity even after low dose of exposure [5].

Accumulating epidemiological evidences suggest an association between OCPs with disease related with metabolic disorders in glucose and lipids. Increased serum levels of OCPs are positively associated with increased prevalence of diabetes and metabolic syndrome [6-9], homeostasis model assessment of insulin resistance (HOMA-IR) [10-12] and cardiovascular disease[13]. However, the underlying mechanisms remain unclear yet. Among all the OCPs, more substantial evidences confirm positive association between higher $\mathrm{p}$ ', $\mathrm{p}$ '-dichloroethylene (p', p'-DDE) level in adipose tissue and diabetes [14] and DDE [15] and hexachlorocyclohexane $(\mathrm{HCH})[16]$ exposure are associated with body size in human. These studies collectively suggest the potential importance of OCPs leading to metabolic disorders in human.

Dyslipidemia are known to be risk factors for gallstone disease $[17,18]$, which is a common disease in western countries. Our recent survey in Shanghai city, China showed its incidence climbing up to $13.7 \%$ (Jiang $\mathrm{ZY}$, et al. unpublished). Interestingly, in a previous casecontrol study, OCPs residues in serum were found to be higher in patients with gallstone disease in the area of Xiamen, China [19]. Since the serum OCPs levels are influenced by dietary lipids, they cannot reflect the burden of OCPs accumulation in body. However, the difficulties to obtain human adipose tissues, which can only be collected during surgical operation, make it a barrier to study the accumulation of OCPs in adipose tissue in association with certain diseases.

Whether OCPs lead to pathophysiological changes associated with gallstone disease through its effect on lipid metabolism in liver has never been investigated. In this study, OCPs levels were analyzed in a unique collection of omentum adipose tissues samples obtained during abdominal operation from patients with and without gallstone. In subgroups of gallstone patients with high and low OCPs levels, liver biopsy samples were also obtained in order to compare the hepatic expression of genes involving lipid metabolism between groups. Furthermore, the regulation of hepatic genes by OCPs was confirmed using HepG2 cell lines in vitro.

\section{RESULTS}

\section{Characteristics of the study population and comparison of OCPs residues in adipose tissues between patients with and without gallstone disease}

The characteristics of the gallstone and the gallstone-free patients are presented in Table 1. There were no significant differences in the age, gender distribution or BMI between two groups.

Among the 12 OCPs detected in adipose tissues (Figure 1), the detected percentage of $\mathrm{HCB}, \beta-\mathrm{HCH}$ and p', p'-DDE were $100 \%$, and $26.2 \%$ for $\alpha-\mathrm{HCH}$. For other types of OCPs, they were below the detection level in any of the subjects.

The mean concentrations of p', p'-DDE and $\beta$-HCH were 2222 and 294.3 (ng/g of lipid) in patients with gallstone disease, and 2025 and 282.7 (ng/g of lipid) in gallstone-free patients (Table 1). p', p'-DDE and $\beta-\mathrm{HCH}$ concentrations in patients with gallstone disease were significantly higher than those in gallstone-free patients $(P<0.05)$, whereas the concentration of HCB showed no difference between the groups (Figure 2). Power analysis was $>90 \%$ at $\alpha=0.05$ level suggesting the satisfaction of sample size in the present study.

\section{High adipose OCPs levels positively associated with gallstone disease}

Based on the fourth quartile of OCPs in all of the patients, quartile division was applied to divide the subjects into 4 subgroups for trend analysis and elucidation of the dose-response for gallstone risk of each OCP. After adjusted for age, gender and BMI, p', p'-DDE levels was significantly associated with gallstone risk, with ORs $(95 \% \mathrm{CI})$ for the quartile 2 to quartile 4 of 3.49 (1.936.33), $2.38(1.32-4.27)$ and $2.48(1.38-4.46)$, respectively (p-trend $=0.0138$, Table 2). A similar association was also found between $\beta-\mathrm{HCH}$ quartiles and the risk of gallstone [ORs $(95 \% \mathrm{CI})$ for the 3rd and 4th quartiles of 3.70 (2.03-6.74) and $1.81(1.02-3.23)$, respectively (p-trend = $0.0004)$, Table 2]. However, there was no association for $\mathrm{HCB}$ levels with gallstone disease.

Correlations between OCPs and serum glucose and lipids were analyzed by multivariate logistic regression. Only a positive correlation between $\beta-\mathrm{HCH}$ and glucose was found after adjusted with age, gender and BMI $(\mathrm{OR}=1.215$ 95\%CI: 1.006-1.468, $\mathrm{P}=0.04$, Table 3$)$. 


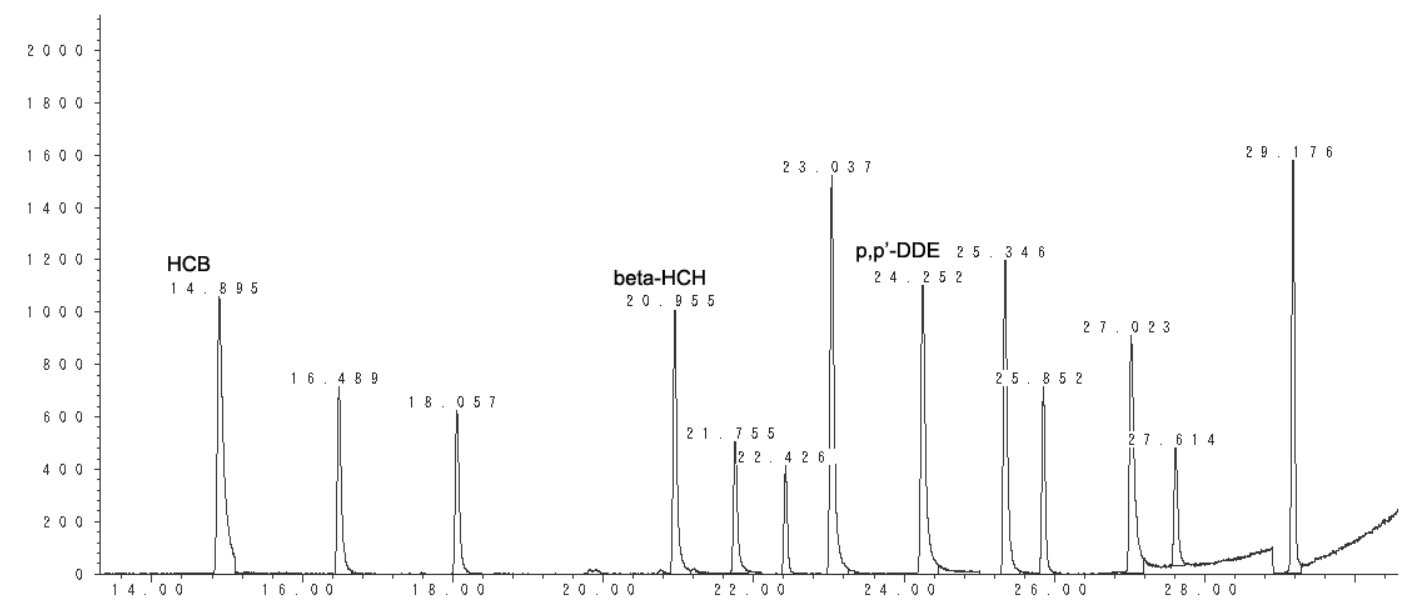

time

Target ions of contaminants in the GC-MS Method

\begin{tabular}{lcc}
\hline Name & & \\
& $\mathrm{t}_{\mathrm{R}} / \mathrm{min}$ & Target ions \\
\hline$o, p^{\prime}$-DDD & 25.3 & 235 \\
$o, p^{\prime}$-DDE & 23.0 & 246 \\
$o, p^{\prime}$-DDT & 25.8 & 235 \\
$p, p^{\prime}$-DDD & 27.0 & 235 \\
$p, p^{\prime}$-DDE & 24.2 & 246 \\
$p, p^{\prime}$-DDT & 27.6 & 235 \\
$\alpha-\mathrm{HCH}$ & 16.5 & 181 \\
$\beta$-HCH & 20.9 & 181 \\
$\gamma-\mathrm{HCH}$ & 18.1 & 181 \\
$\delta$-HCH & 21.7 & 181 \\
hexachlorobenzene & 14.9 & 284 \\
mirex & 29.2 & 272 \\
\hline
\end{tabular}

Figure 1: Chromatogram of 12 organochlorine pesticides (upper part) and the target ions of contaminants in the GCMS method (lower part). 
Table 1: Main characteristics of the subjects by gallstone status.

\begin{tabular}{|c|c|c|c|}
\hline Characteristic & $\begin{array}{l}\text { Gallstone-free } \\
(N=190)\end{array}$ & \begin{tabular}{|l|} 
Gallstone \\
$(N=194)$
\end{tabular} & $P$ \\
\hline Age (years, mean \pm SD) & $58.47 \pm 16.02$ & $56.38 \pm 13.35$ & $0.165^{\mathrm{a}}$ \\
\hline Gender & & & $0.269^{\mathrm{b}}$ \\
\hline Males & 87 & 78 & \\
\hline Females & 103 & 116 & \\
\hline BMI (mean \pm SD) & $24.37 \pm 2.86$ & $24.41 \pm 3.33$ & $0.8997^{\mathrm{a}}$ \\
\hline HCB (ng/g of lipid) & & & $0.2840^{\mathrm{c}}$ \\
\hline Median & 62.04 & 59.27 & \\
\hline Min-Max & $2.732-320.6$ & $6.576-516.7$ & \\
\hline Percentiles $10-90$ & $35.48-107.24$ & $20.80-139.6$ & \\
\hline$p, p^{\prime}-\mathrm{DDE}$ (ng/g of lipid) & & & $0.0080^{c}$ \\
\hline Median & 1213 & 1542 & \\
\hline Min-Max & $19.93-17261$ & $12.83-18135$ & \\
\hline Percentiles 10-90 & $231.3-4108$ & $29.06-9991$ & \\
\hline$\beta-\mathrm{HCH}$ (ng/g of lipid) & & & $0.0006^{\mathrm{c}}$ \\
\hline Median & 92.01 & 233.5 & \\
\hline Min-Max & $12.45-3536$ & $7.91-3088$ & \\
\hline Percentiles 10-90 & $33.46-805.4$ & $33.50-622.3$ & \\
\hline
\end{tabular}

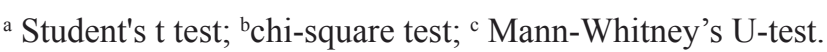

Table 2: Risk of gallstone disease in association with organochlorine pesticides in adipose tissues

\begin{tabular}{|c|c|c|c|}
\hline $\begin{array}{l}\text { Compound/concentration } \\
\text { (ng/g of lipid weight) }\end{array}$ & $\begin{array}{l}\text { Control } \\
N=190\end{array}$ & $\begin{array}{l}\text { Case } \\
N=194\end{array}$ & OR (95\% CI) \\
\hline & $N(\%)$ & $N(\%)$ & \\
\hline \multicolumn{4}{|l|}{$\mathrm{HCB}$} \\
\hline $2.73-41.1$ & $41(21.6)$ & $55(28.4)$ & 1.00 \\
\hline $41.1-61.68$ & $52(27.4)$ & $44(22.7)$ & $0.63(0.36,1.12)$ \\
\hline $61.68-84.62$ & $49(25.8)$ & $47(24.2)$ & $0.72(0.40,1.26)$ \\
\hline $84.62-516.7$ & $48(25.3)$ & $48(24.7)$ & $0.75(0.42,1.32)$ \\
\hline$P$-value for trend & 0.8254 & & \\
\hline \multicolumn{4}{|l|}{$p, p^{\prime}-\mathrm{DDE}$} \\
\hline $12.83-721.7$ & $65(34.2)$ & $31(16.0)$ & 1.00 \\
\hline $721.7-1351$ & $36(18.9)$ & $60(30.9)$ & $3.49(1.93,6.33) *$ \\
\hline $1351-2558$ & $45(23.7)$ & $51(26.3)$ & $2.38(1.32,4.27) *$ \\
\hline $2558-18135$ & $44(23.2)$ & $52(26.8)$ & $2.48(1.38,4.46) *$ \\
\hline$P$-value for trend & 0.0138 & & \\
\hline \multicolumn{4}{|l|}{$\beta-\mathrm{HCH}$} \\
\hline $7.91-59.18$ & $58(30.5)$ & $38(19.6)$ & 1.00 \\
\hline $59.18-174.8$ & $61(32.1)$ & $35(18.0)$ & $0.86(0.48,1.54)$ \\
\hline $174.8-363.8$ & $28(14.7)$ & $69(35.6)$ & $3.70(2.03,6.74) *$ \\
\hline $363.8-3536$ & $43(22.6)$ & $52(26.8)$ & $1.81(1.02,3.23) *$ \\
\hline$P$-value for trend & 0.0004 & & \\
\hline
\end{tabular}

${ }^{a}$ ORs adjusted for age, gender and BMI. ${ }^{*} P<0.05$ compared with the lowest pesticides concentration.

\section{High OCPs level in adipose tissue contributed to disorders of hepatic lipids metabolism in patients}

The main defect led to gallstone formation is hypersecretion of cholesterol into bile by liver $[17,20]$. We next investigated whether $\beta-\mathrm{HCH}$ and p', p'-DDE levels were related with disorders in hepatic lipid metabolism in gallstone patients. Liver biopsies were obtained from a subgroup of gallstone patients. The patients were classified into three quartiles according to the level of both $\beta-\mathrm{HCH}$ and p', p'-DDE in adipose tissue. The highest tertile of both OCPs was designated as high-level group and the 
A

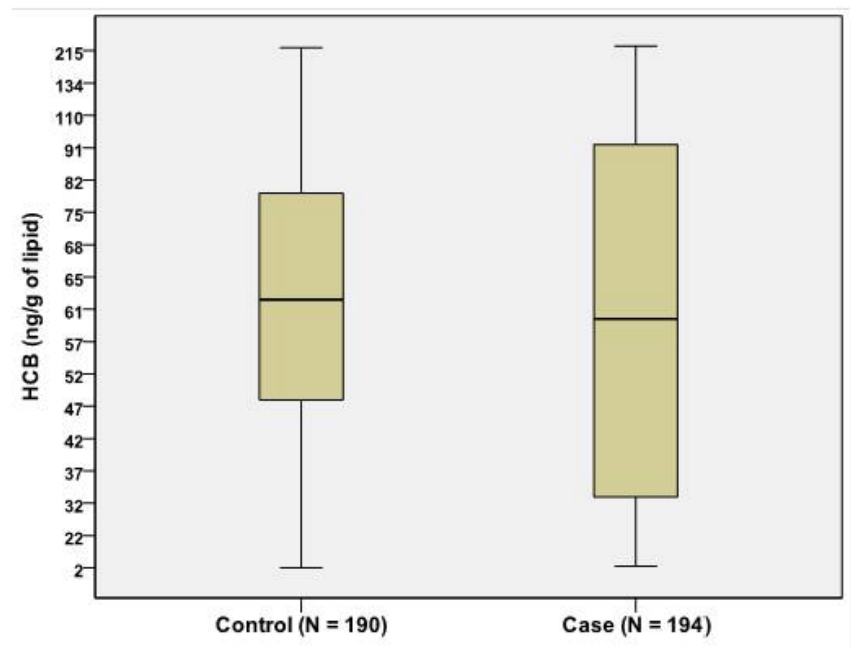

B

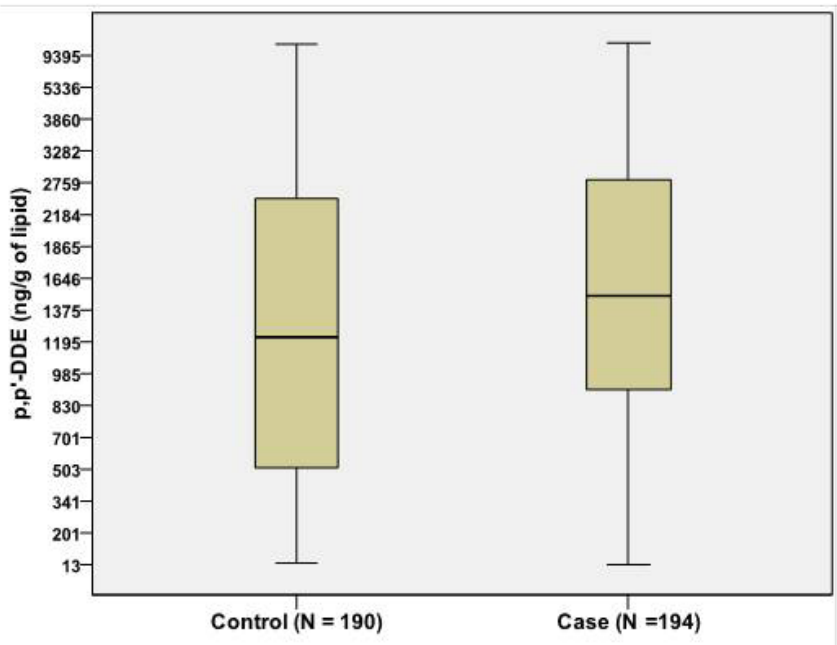

C

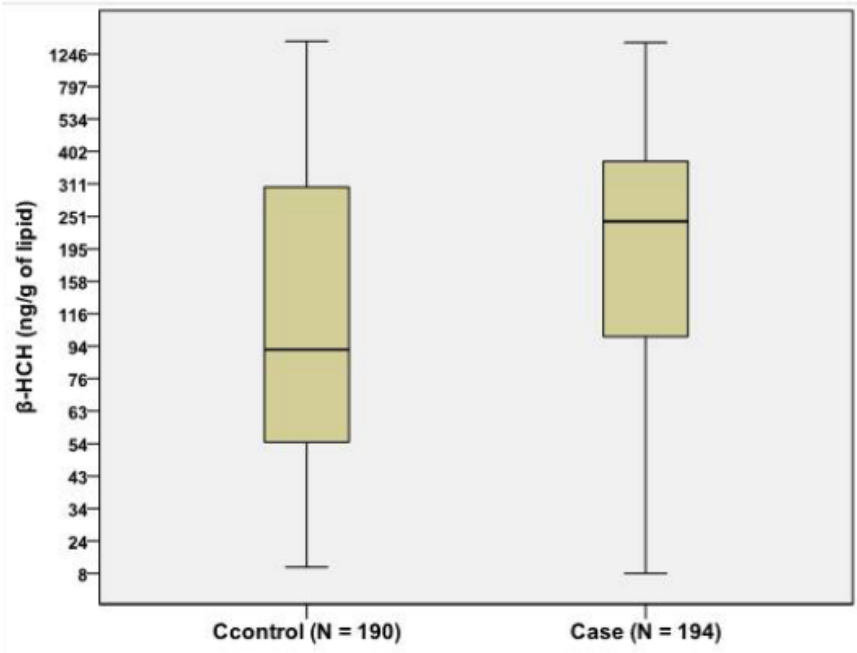

Figure 2: Comparison of OCPs between patients with gallstone disease (case) and gallstone-free controls (control). No difference was found for HCB A. between groups. Both $\beta-\mathrm{HCH}$ B. and p', p'-DDE C. content were significantly higher in gallstone patients (case) than in gallstone-free controls (control), $P<0.05$. 
Table 3: Multivariate analysis for $\beta$-HCH levels in human adipose tissue and biochemical index $(n=194)$.

\begin{tabular}{|l|l|l|l|l|}
\hline Variables & Coef. $^{{ }^{a}}$ & Std. err. & 95\%Conf. interval & $P$-value \\
\hline Blood glucose & 0.195 & 0.096 & $0.006,0.384$ & 0.044 \\
\hline Total cholesterol & -0.020 & 0.074 & $-0.166,0.126$ & 0.786 \\
\hline Triglyceride & 0.013 & 0.047 & $-0.080,0.106$ & 0.785 \\
\hline High density lipoprotein & -0.001 & 0.052 & $-0.103,0.101$ & 0.985 \\
\hline Low density lipoprotein & -0.057 & 0.108 & $-0.271,0.157$ & 0.599 \\
\hline ALT & -5.97 & 5.22 & $-16.3,4.33$ & 0.255 \\
\hline AST & -3.41 & 2.29 & $-7.93,1.11$ & 0.138 \\
\hline Apolipoprotein $A^{\text {b }}$ & -0.011 & 0.026 & $-0.063,0.041$ & 0.680 \\
\hline Apolipoprotein $\mathrm{B}^{\mathrm{b}}$ & -0.022 & 0.028 & $-0.076,0.033$ & 0.435 \\
\hline NEFA $^{\mathrm{b}}$ & -0.005 & 0.030 & $-0.065,0.055$ & 0.874 \\
\hline Apolipoprotein $\mathrm{E}^{\mathrm{b}}$ & 0.897 & 1.88 & $-2.82,4.61$ & 0.633 \\
\hline
\end{tabular}

${ }^{a}$ Regression coefficients were adjusted for age, gender, and BMI; ${ }^{b} \mathrm{~N}=163$. Abbrieviation: ALT: alanine aminotransferase; AST: aspartate aminotransferase; NEFA: non-esterified fatty acids.

Table 4: Comparison of biliary lipid composition between high-level OCPs group and low-level OCPs group (means \pm SEM)

\begin{tabular}{|l|l|l|}
\hline & High-level group & Low-level group \\
\hline Cholesterol (molar\%) & $8.4 \pm 0.6$ & $7.3 \pm 0.4$ \\
\hline Bile acids (molar\%) & $70.5 \pm 1.6$ & $68.1 \pm 2.8$ \\
\hline Phospholipids (molar\%) & $21.8 \pm 1.5$ & $24.7 \pm 2.7$ \\
\hline Total lipids (g/L) & $10.3 \pm 1.1$ & $10.8 \pm 0.9$ \\
\hline CSI & $1.25 \pm 0.09^{*}$ & $1.03 \pm 0.05$ \\
\hline
\end{tabular}

$* P<0.05$ when compared with low-level group by t-test
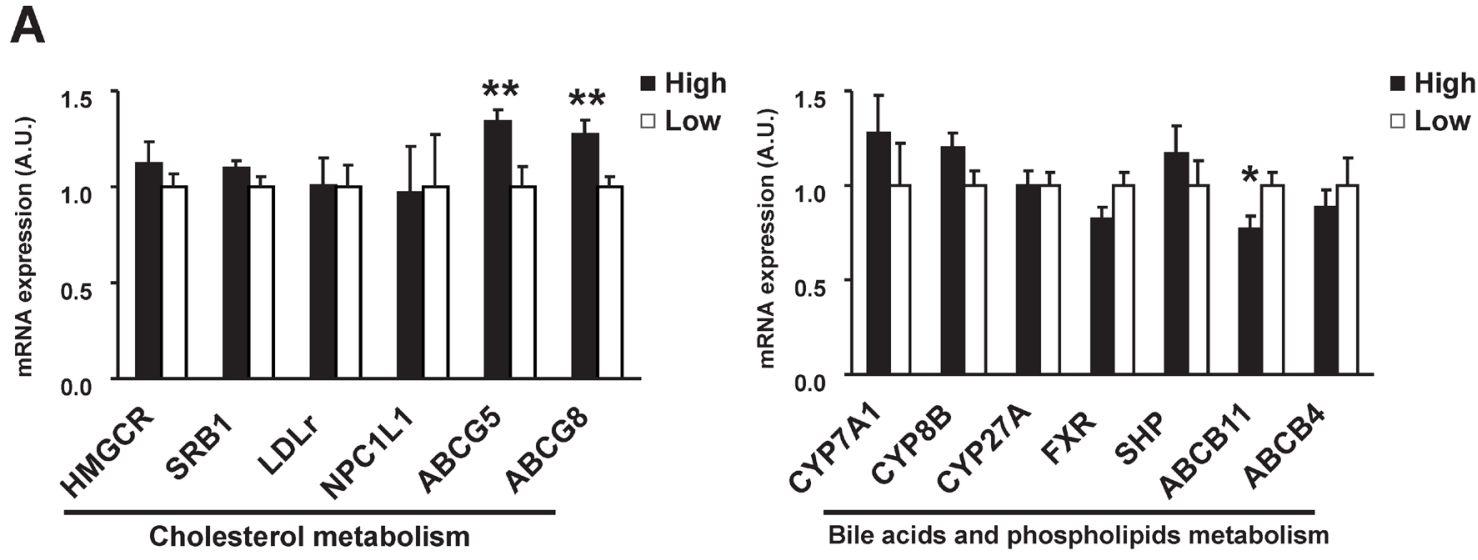

B

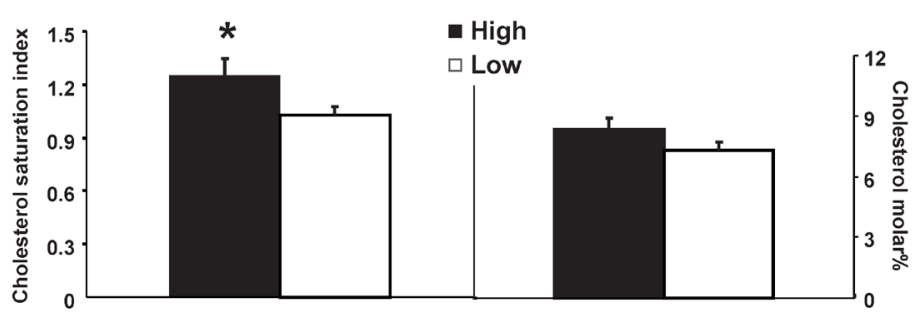

C

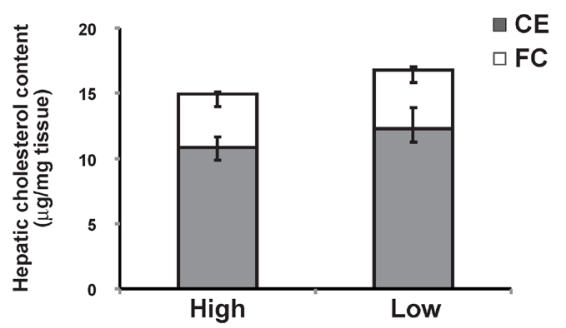

Figure 3: Comparison of hepatic gene expressions between high OCPs (p', p'-DDE and $\beta$-HCH) level group $(n=17)$ and low level group $(\boldsymbol{n}=\mathbf{1 9})$. A. Genes involved in cholesterol, phospholipids and bile acid metabolism; B. Cholesterol saturation index and cholesterol molar\% in gallbladder bile; $\mathbf{C}$. Free cholesterol and cholesteryl ester level in liver. Data were expressed as means \pm SEM. '*' represents $P<0.05$ and '**' represents $P<0.01$. 
lowest tertile as low-level group. Gene expression levels in the pathway of cholesterol, bile acids, phospholipids and fatty acids metabolism were measured.

ABCG8, together with ABCG5, forms heterodimers in the canalicular membrane of hepatocytes and are responsible for the secretion of hepatic cholesterol into bile $[21,22]$. The mRNA expressions of both $A B C G 5$ and $A B C G 8$ were significantly higher in the highlevel group $(+34 \%$ and $+27 \%, \mathrm{P}<0.01$, Figure $3 \mathrm{~A})$. This change was accompanied with higher cholesterol saturation index $(\mathrm{CSI}, \mathrm{P}<0.05)$ in gallbladder bile in the high-level group compared with the low-level group as well as a trend of higher cholesterol molar\% (Figure 3B and Table 4). Positive correlation was found for $\beta-\mathrm{HCH}$ in association with $A B C G 5(\mathrm{r}=0.47), A B C G 8(\mathrm{r}=0.35)$ expression and CSI $(\mathrm{r}=0.50), \mathrm{P}<0.05$, as well as for $\mathrm{p}$,
p'-DDE ( $\mathrm{r}=0.47,0.39$ and 0.48 , respectively, $\mathrm{P}<0.05)$. These results suggested that higher $\beta-\mathrm{HCH}$ and p', p'DDE might promote hyper-secretion of biliary cholesterol which favors gallstone formation via hepatic ABCG5/ G8. The genes involved in hepatic cholesterol synthesis or absorption did not differ (Figure 3A). The mRNA expressions of the key enzymes for hepatic bile acid synthesis were about the same between groups. The canalicular bile salt export pump, $A B C B 11$, was $23 \%$ lower in high-level group $(\mathrm{P}<0.05$, Figure $3 \mathrm{~A})$, suggesting the existence of decreased secretion of biliary bile salts in these patients as well.

Interestingly, the key enzymes in fatty acid synthesis, fatty acid synthase $(F A S)$ and stearoyl CoA desaturase $1(S C D 1)$, were $71 \%$ and $99 \%$ higher in the high-level group, respectively (Figure 4A) as well as
A

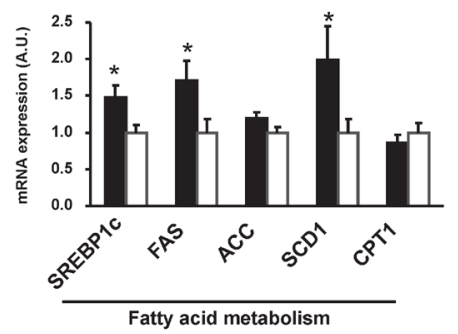

B

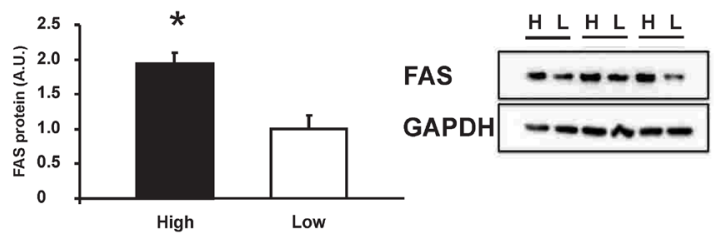

C

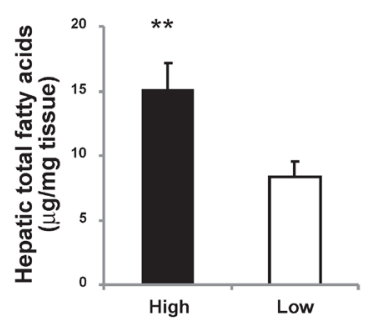

D
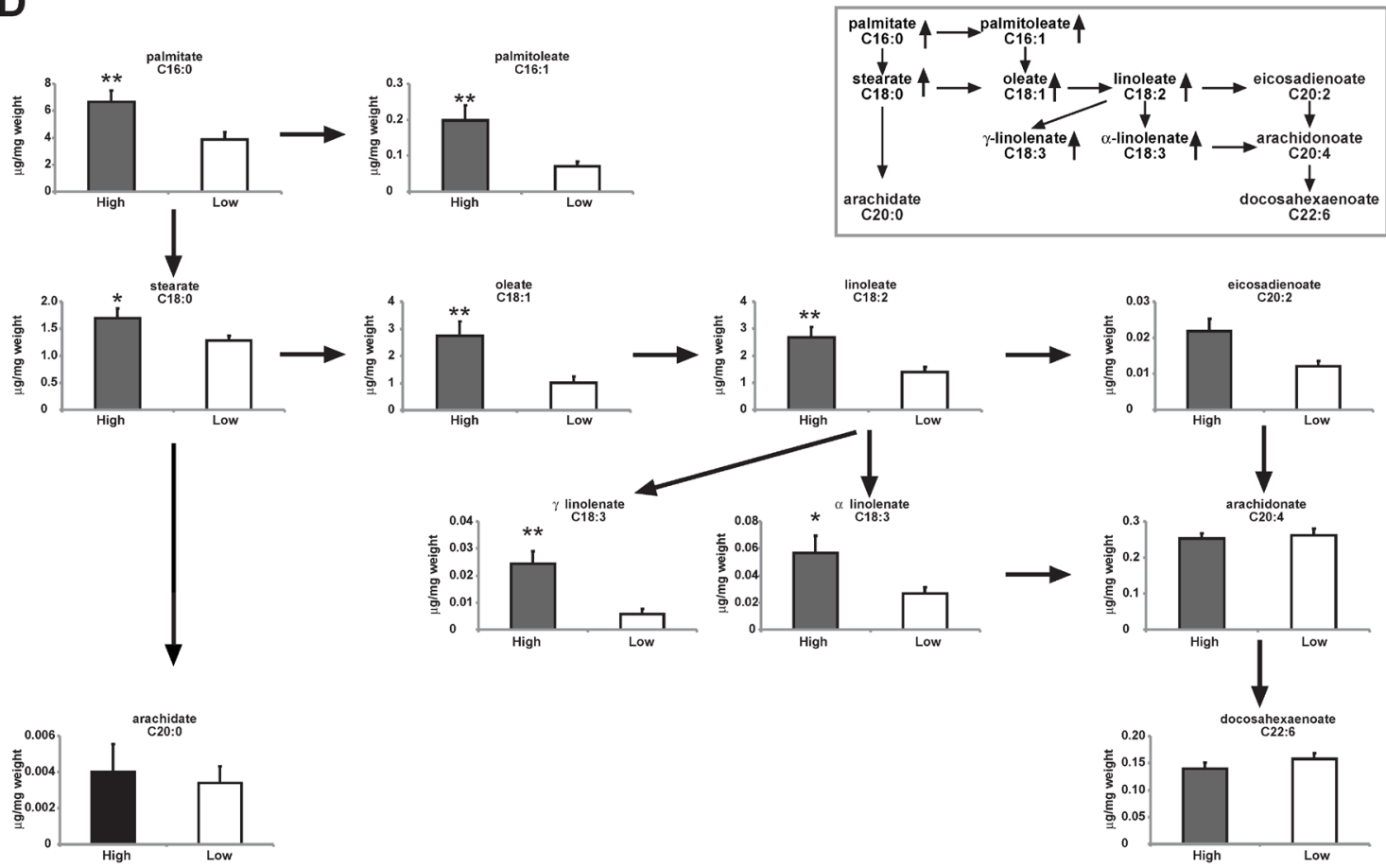

Figure 4: Comparison of hepatic fatty acid metabolism between high OCPs (p', p'-DDE and $\beta$-HCH) level group and low level group. A. mRNA expression of genes involved in fatty acid metabolism. B. Protein level of FAS in pooled liver homogenates from high OCPs level group $(\mathrm{H})$ and low level group (L). C. Hepatic total fatty acids content. D. Hepatic individual fatty acid contents. The pathway of main fatty acids was shown in the in-set figure. Data were expressed as means $\pm \mathrm{SEM}$. '*' represents $P<0.05$ and '**' represents $P<0.01$. 
Table 5: Comparison of OCPs levels in adipose tissues in subjects from different countries

\begin{tabular}{|c|c|c|c|c|c|c|c|c|c|}
\hline No & Source & Country & year & number & Age(years) & HCB & $\beta$-НСН & DDE & References \\
\hline 1 & $\begin{array}{l}\text { Abdominal } \\
\text { adipose tissue }\end{array}$ & Belgium & $\begin{array}{l}1998- \\
2007\end{array}$ & 98 & $>18$ & N/A & 19 & 205 & $\begin{array}{l}\text { Obesity 2011; } \\
\text { 19: 709-714 a }\end{array}$ \\
\hline 2 & $\begin{array}{l}\text { Abdominal } \\
\text { adipose tissue }\end{array}$ & Belgium & 2000 & 20 & $19-77$ & 46 & N/A & 280 & $\begin{array}{l}\text { Environ } \quad \text { Res } \\
2002 ; 88: 210 \mathrm{a}\end{array}$ \\
\hline 3 & $\begin{array}{l}\text { Breast adipose } \\
\text { tissue }\end{array}$ & Canada & $\begin{array}{l}1995- \\
1997\end{array}$ & $\begin{array}{l}217 \text { cases } \\
213 \\
\text { controls }\end{array}$ & $\begin{array}{l}\text { average: } \\
57.7 \quad \text { vs } \\
53.9\end{array}$ & $\begin{array}{ll}32.0 & \text { vs } \\
30.1 & \end{array}$ & $\begin{array}{l}43.1 \quad \text { vs } \\
41.5\end{array}$ & $\begin{array}{l}693 \\
596\end{array} \quad$ vs & $\begin{array}{l}\text { Cancer } \\
\text { Epidemiol } \\
\text { Biomarker Prev } \\
\text { 2000; 9: 55 a } \\
\end{array}$ \\
\hline 4 & $\begin{array}{l}\text { Breast adipose } \\
\text { tissue }\end{array}$ & USA & $\begin{array}{l}1994- \\
1997\end{array}$ & $\begin{array}{l}186 \text { cases } \\
304 \\
\text { controls }\end{array}$ & $40-79$ & N/A & N/A & $\begin{array}{l}772.8 \text { vs } \\
789.5^{*}\end{array}$ & $\begin{array}{l}\text { Am J } \\
\text { Epidimiology } \\
1999 ; 150: 453 \mathrm{a}\end{array}$ \\
\hline 5 & $\begin{array}{l}\text { Omentum } \\
\text { adipose tissue }\end{array}$ & $\begin{array}{l}\text { China, } \\
\text { Shanghai }\end{array}$ & $\begin{array}{l}2008- \\
2009\end{array}$ & $\begin{array}{l}190 \text { cases } \\
190 \\
\text { controls } \\
\end{array}$ & $17-79$ & 67.8 & 282 & 2025 & $\begin{array}{l}\text { The present } \\
\text { study a }\end{array}$ \\
\hline 6 & $\begin{array}{l}\text { Breast adipose } \\
\text { tissue }\end{array}$ & Mexico & NA & 60 & $18-44$ & 60 & 140 & 4360 & $\begin{array}{l}\text { Arch Environ } \\
\text { Contam Toxicol } \\
\text { 2001; 40: } 432 \mathrm{a}\end{array}$ \\
\hline 7 & $\begin{array}{l}\text { Subcutaneous } \\
\text { adipose tissue }\end{array}$ & Poland & $\begin{array}{l}1989- \\
1992\end{array}$ & 277 & $10-80$ & 310 & 228 & 5745 & $\begin{array}{l}\text { Bull Environ } \\
\text { Contam Toxicol } \\
\text { 1994; 52: } 40 \mathrm{a} \\
\end{array}$ \\
\hline 8 & Serum & USA & \begin{tabular}{|l}
$1999-$ \\
2004 \\
\end{tabular} & 4433 & $20-85$ & 11.3 & 10.1 & 389.5 & $\begin{array}{l}\text { The NHANES } \\
\text { survey } \mathrm{b}\end{array}$ \\
\hline 9 & Serum & $\begin{array}{l}\text { China, } \\
\text { Xiamen }\end{array}$ & $\begin{array}{l}2009- \\
2010\end{array}$ & $\begin{array}{l}150 \text { cases } \\
150 \\
\text { controls } \\
\end{array}$ & \begin{tabular}{|l|} 
average: \\
$47.71 \quad$ vs \\
48.35
\end{tabular} & $\mathrm{~N} / \mathrm{A}$ & $\begin{array}{l}2.881 \text { vs } \\
7.986\end{array}$ & $\begin{array}{l}1.137 \text { vs } \\
0.677\end{array}$ & $\begin{array}{l}\text { Ann Epidemiol } \\
\text { 2012; 22: } 592 \mathrm{c}\end{array}$ \\
\hline 10 & Serum & $\begin{array}{l}\text { Shanghai, } \\
\text { China }\end{array}$ & $\begin{array}{l}2013- \\
2014\end{array}$ & $\begin{array}{l}124 \text { cases } \\
109 \\
\text { controls } \\
\end{array}$ & $3-6$ & $\begin{array}{ll}46.12 & \text { VS } \\
22.86 & \end{array}$ & $\begin{array}{l}111.11 \mathrm{vs} \\
31.49\end{array}$ & $\begin{array}{l}166.52 \\
\text { Vs } \\
6.97 \\
\end{array}$ & $\begin{array}{l}\text { Enviromental } \\
\text { Res 2016; } \\
46: 125\end{array}$ \\
\hline 11 & Whole blood & Japan, & $\begin{array}{l}2002- \\
2005\end{array}$ & 186 & $17-47$ & 100 & 150 & 610 & $\begin{array}{l}\text { Science Total } \\
\text { Environment } \\
\text { 2012; 426: 73. d }\end{array}$ \\
\hline
\end{tabular}

a: unit=ng/g of lipid weight; b: unit=ng/L; c: $\mu \mathrm{g} / \mathrm{L} ; \mathrm{d}: \mathrm{pg} / \mathrm{g}$ wet mass of whole blood; *: geometric means

the protein level of FAS (Figure 4B). Hepatic total fatty acids level was also significantly higher in the high-level group than the low-level group (Figure 4B) suggesting an enhanced lipogenesis in patients with high level of adipose OCPs. The differences in profile of individual fatty acid between the two groups were shown in Figure 4D. A more in-depth insight into patterns of individual fatty acids in high-level group and low-level group was shown in Figure 5. The increase of fatty acid synthesis might be activated by sterol response element binding protein 1c (SREBP1c) [23], which was $48 \%$ higher in the high-level group (Figure 4A).

Carnitine palmitoyl transferase 1 (CPT1), which is responsible for the fatty acid $\beta$-oxidation, did not differ between groups (Figure 4A). No difference was observed for free cholesterol or cholesteryl ester levels in liver either (Figure 3C), suggesting no excessive accumulation and esterification of cholesterol in liver.

\section{OCP induced genes involving lipid metabolism in HepG2}

Because the co-existence of OCPs in human tissues, we incubated human hepatoma cell line - HepG2 with either $\beta$-HCH or p', p'-DDE separately to differentiate the role of each OCP. $\beta$-HCH induced FAS, SCD1 SREBP1c and ABCG8 expression in HepG2 cells dose-dependently (Figure 6B and 6D). Similar effect was observed when incubated with p', p'-DDE (Figure 6A and 6C). These data suggested $\beta-\mathrm{HCH}$ and p', p'-DDE could synergistically influence hepatic lipid metabolism of cholesterol and fatty acids.

\section{DISCUSSION}

This study for the first time investigated the association of OCPs levels in omentum adipose tissues with gallstone disease and molecular changes in lipid metabolism in human liver. We found $\beta-\mathrm{HCH}$ and p', p'-DDE levels in adipose tissues were higher in patients 
with gallstone disease (Table 1 and Figure 2) and strongly positively related with gallstone disease (Table 2). Our results also showed that higher OCPs in adipose tissue led to increased expression of cholesterol transporters ABCG5/G8 in liver, higher cholesterol saturation index in gallbladder bile in patients (Figure 3), as well as increased hepatic lipogenesis (Figure 4 and 5). Both $\beta-\mathrm{HCH}$ and p', p'-DDE could induce the expression of genes involved in cholesterol excretion and fatty acid synthesis in HepG2 cells (Figure 6).

Due to their lipophilic property, OCPs can accumulate in adipose tissues and other organs. They are resistant to degradation in the body and can exert their influences persistently. However, only limited studies have measured the levels of OCPs in human adipose tissues collected from patients at different regions (Table 5): in breast adipose tissues [24-26] and in subcutaneous adipose tissue $[16,27,28]$. Though limited, these data collectively provide evidences for substantial accumulation of OCPs in non-occupational populations even long after banning of the usage of OCPs. The OCPs level in adipose tissue were fold-higher in our subjects from East China compared with data from Belgium, Canada and US, but less than that from Mexico or Poland. OCPs still can be detected in water [1] and the residual levels of OCPs in animal meats such as fish, beef, etc [29]. The levels of OCPs in adipose tissue may more reflect the burden of OCPs exposure in body and it has the advantage of less influence by dietary lipids than serum or plasma. Albeit, much attention has been paid concerning serum OCPs in association with various diseases such as cardiovasulcar disease, diabetes, metabolism syndrome [6-9] due to the difficulty in obtaining adipose tissue in the populations. Therefore, in this study, we collected omentum adipose tissue in patients and found strongly positive association between OCPs levels and gallstone disease.

Our finding that subjects with higher $\beta-\mathrm{HCH}$ and p', p'-DDE levels in adipose tissues were at higher risk of developing gallstone disease is in line with $\mathrm{Su}$ et al's [19]. More importantly, we found both mRNA of ABCG5 and ABCG8 were higher in patients with high OCPs level. Hepatic ABCG8 expression was induced by both $\beta-\mathrm{HCH}$

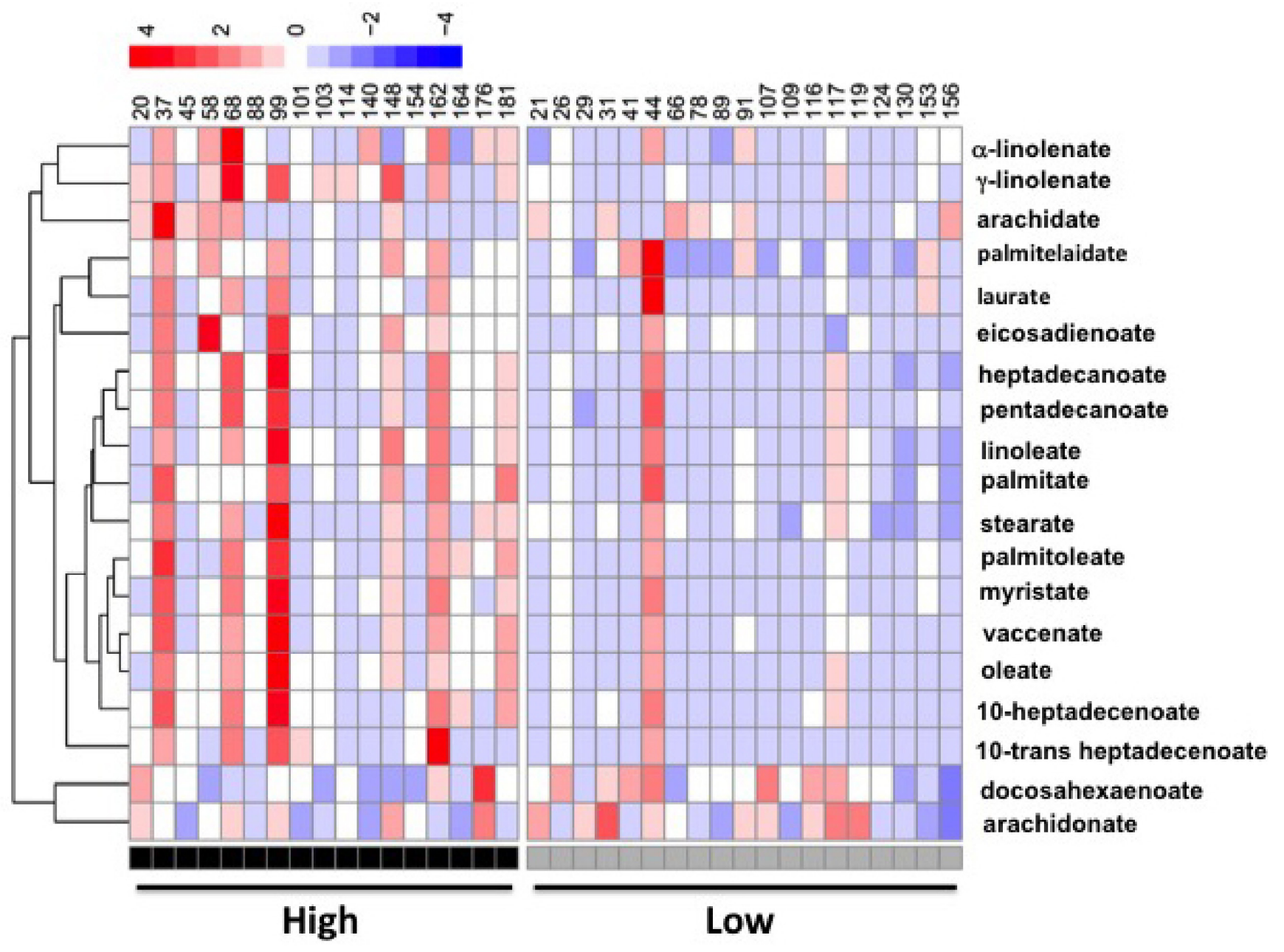

Figure 5: A heatmap display of quantitative analysis of all individual fatty acids in liver between patients with high OCPs (p', p'-DDE and $\beta$-HCH) level and low OCPs level. 
A

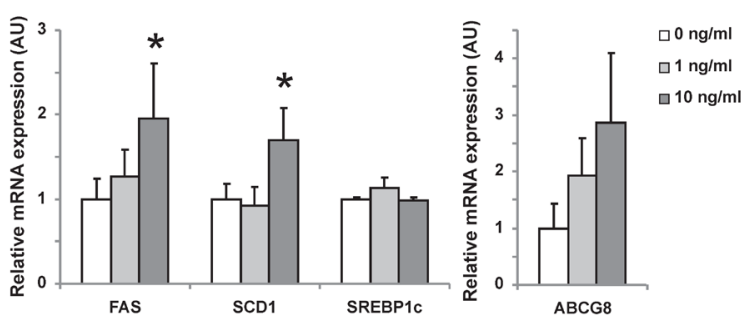

C

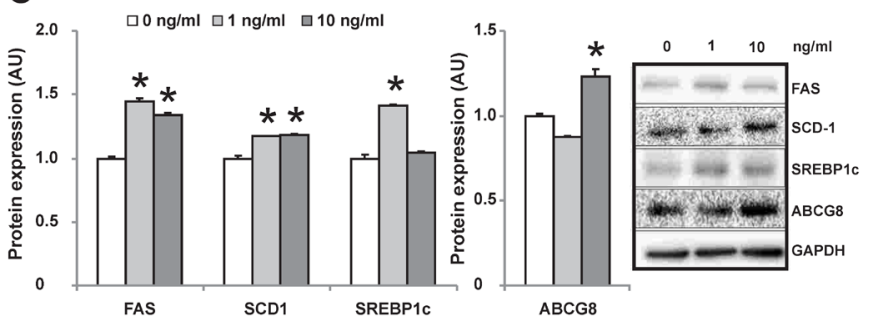

B

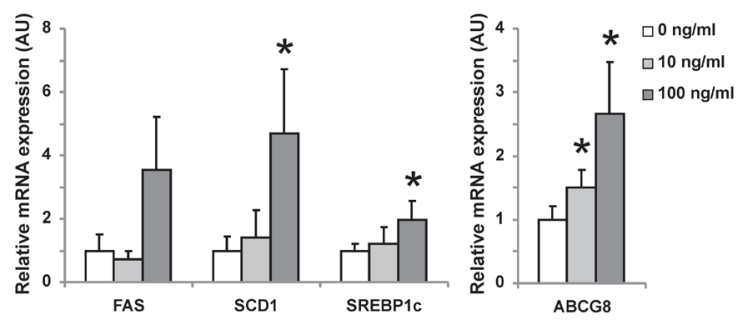

D

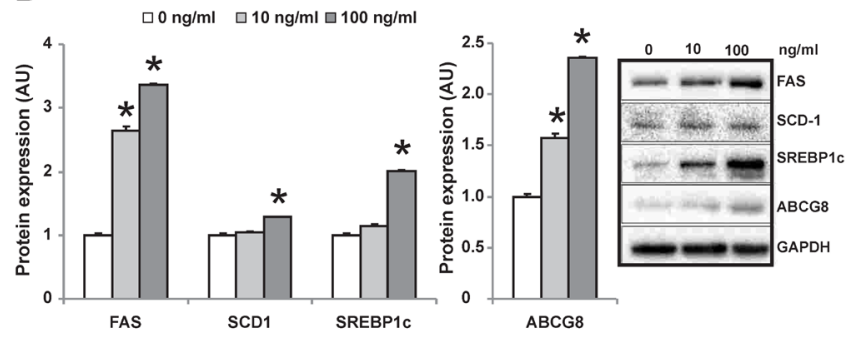

Figure 6: Changes of gene expression in HepG2 cells after incubated with individual OCP. mRNA A. and protein expression C. of genes in HepG2 cells incubated with increased concentration of p', p'-DDE $(0,1,10 \mathrm{ng} / \mathrm{mL})$. mRNA B. and protein expression D. of genes in HepG2 cells incubated with increased concentration of $\beta-\mathrm{HCH}(0,10,100 \mathrm{ng} / \mathrm{mL})$. '*' represents $P<0.05$ as compared with the concentration at $0 \mathrm{ng} / \mathrm{mL}$.

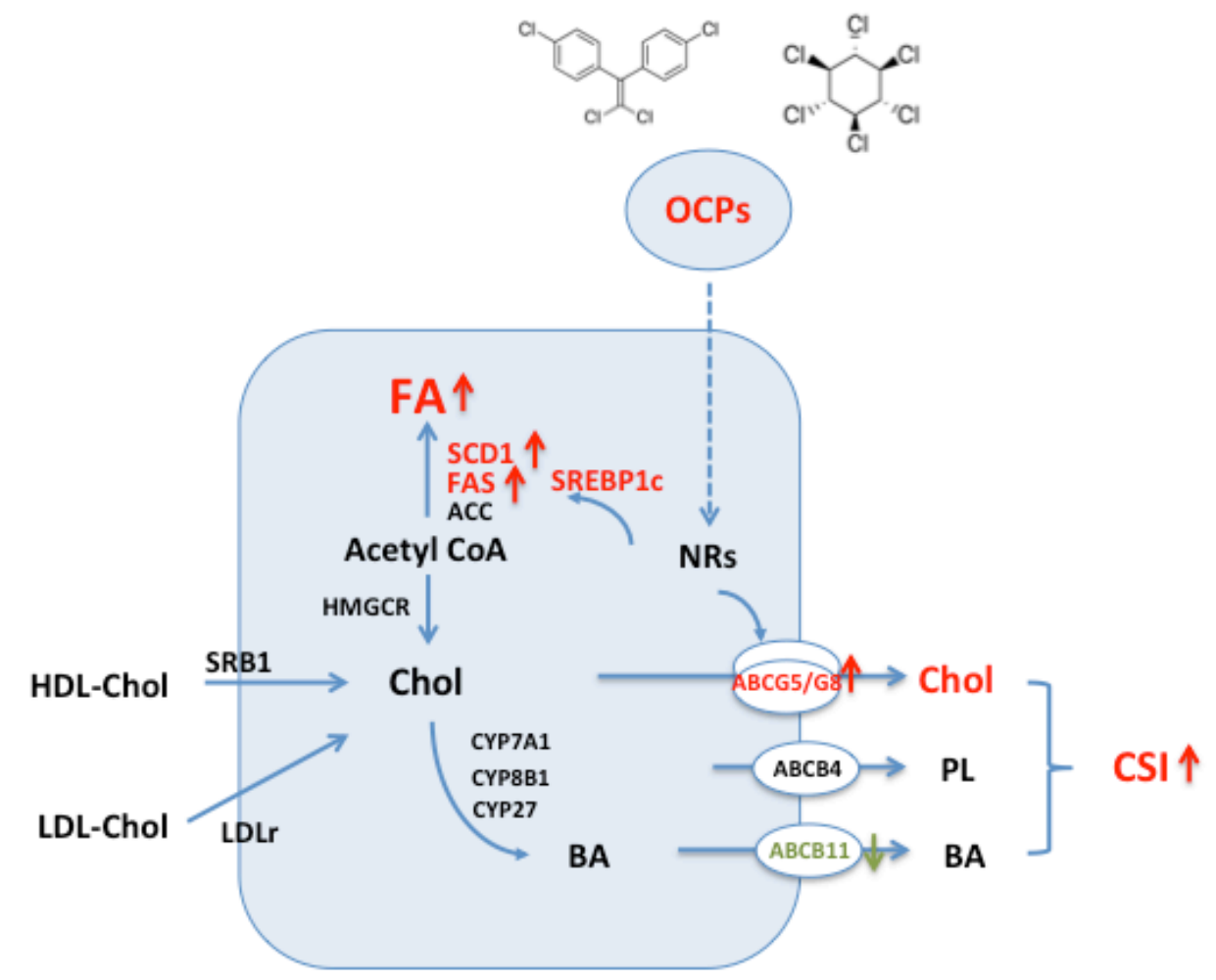

Figure 7: Schematic showing changes of hepatic lipid metabolism in hepatocyte exposed to high level of organochlorine pesticides (p', p'-DDE and $\boldsymbol{\beta}$-HCH). (1) Increased hepatic canalicular cholesterol transporters ABCG5 and ABCG8 associated with higher biliary cholesterol saturation index; (2) Increased expression of key enzymes in fatty acid synthesis pathway and high level of hepatic total fatty acid content and fatty acid composition. Abbrieviations: ACC: acetyl-CoA carboxylase; ABC: ATP binding cassette; BA: bile acids; Chol: cholesterol; CSI: cholesterol saturation index; CYP7A1: cholesterol $7 \alpha$-hydroxylase, CYP8B1: cholesterol 12 $\alpha$-hydrolylase; CYP27: cholesterol 27-hydroxylase; FA: fatty acid; FAS: fatty acid synthase; HDL: high density lipoprotein; HMGCR: 3-hydroxy-3methylglutaryl coenzyme A reductase; LDLr: low density lipoprotein receptor; NRs: nuclear receptors; OCPs: organochlorine pesticides; SCD1: stearoyl CoA desaturase 1; SREBP1c: sterol regulatory element biding protein 1c; SRB1: scavenger receptor B type 1. 
and p', p'-DDE in HepG2 cells in vitro. ABCG5/G8 are key players in regulating biliary cholesterol content $[21$, 22]. Increased hepatic expression of ABCG5 and ABCG8 mRNA in gallstone patients has been reported [30], which represents the main defect leading to hyper-secretion of cholesterol in hepatocyte. In the patients with high OCPs level, higher CSI in gallbladder was observed as well, suggesting the presence of an enhanced biliary secretion of cholesterol into bile by hepatocyte. Moreover, we found lower ABCB11 expression in the high-level group suggested presence of decreased biliary bile acid secretion by hepatocytes, even no difference in bile acid synthesis existed.

In this study, we also found defects in hepatic fatty acid synthesis patients with high-level of $\beta-\mathrm{HCH}$ and p', p'-DDE as evidenced by higher expression of FAS, SCD-1, increased hepatic total fatty acid and individual fatty acids contents (Figure 4 and 5). This was due to the activation of hepatic SREBP1c which is the key regulator of lipogenesis gene [23]. Mixed OCPs in high fat diet could induce hepatic SREBP1c expression in rats [31] and led to liver steatosis. In rats fed with high fat diet, p', p'-DDE exposure can induce liver levels of fatty acids as palmitic, stearic, oleic acids [32]. Using HepG2 cells, we also observed an induction of genes in lipogenesis by $\beta-\mathrm{HCH}$ and p', p'-DDE in vitro (Figure 5). These observations are consistent with what we found in human liver from patients with high OCPs levels.

In conclusion, our study provided important data showing the extent of OCPs accumulation in adipose tissue in non-occupational subjects living in East China and found strong association between high OCPs levels in adipose tissue and gallstone disease. The mechanistically molecular changes in hepatic lipid metabolism induced by OCPs were schematically shown in Figure 7. Due to the difficulty to obtain adipose tissue in human, such data are rare and may provide important insights for an understanding the potential chronic influences on hepatic metabolic homeostasis by OCPs. In general population, people are experienced background exposure to OCPs through food consumption. OCPs can accumulate in adipose tissue for decades and are resistant to degradation and such chronic low-level exposure seems not to be risk-free. Our present findings suggest the public health significance of environmental OCPs in relation with metabolic disorders in human.

\section{MATERIALS AND METHODS}

\section{Patients and sample collection}

About 200 800 mg great omentum adipose tissue samples were collected from 194 patients with cholesterol gallstone disease during laparoscopic cholecystectomy between May 2008 and December 2011. A wedge of about $0.2 \sim 0.5$ gram liver biopsies were taken from the edge of right liver during the laparoscopic cholecystectomy in 60 patients with gallstone disease. Cholesterol gallstones were confirmed by visual inspection of the typical cutsurface of gallstones or, when necessary, by enzymatic cholesterol analysis. During the same period, great omentum adipose tissue from 190 gallstone-free patients (as controls) undergoing abdominal surgery unrelated to the gallstone disease (36\% appendicitis surgery, $21 \%$ inguinal hernia, 16\% liver and spleen rupture surgery, and $27 \%$ other surgery). All the controls were proved to be gallstone-free by B-type ultrasonography. All collected tissue samples were snap-frozen in liquid nitrogen, and then stored at $-80^{\circ} \mathrm{C}$ until analysis. The study protocol conformed to the ethical guidelines of the Declaration of Helsinki and was approved by the Ethical Committee at Shanghai East Hospital, Tongji University School of Medicine and Shanghai Ruijin Hospital, Shanghai Jiaotong University School of Medicine. Written informed consent was obtained from each patient.

\section{Organochlorine analyses}

\section{Sample preparation and purification}

The total adipose tissue sample was homogenized twice with $3 \mathrm{~mL}$ of acetonitrile (plus $1 \mathrm{~mL}$ of formic acid). All the homogenate (plus 1 gram of sodium chloride) was collected to centrifuge at $10,000 \mathrm{r} / \mathrm{min}$ for $5 \mathrm{~min}$. The supernatant was cleaned by SPE PSA cartridges (Waters, USA) to remove the impurities, which was washed with $25 \mathrm{~mL}$ of acetonitrile- toluene (3:1). All the eluate was concentrated to about $1 \mathrm{~mL}$ by rotatory evaporator and dried by nitrogen. One $\mathrm{mL}$ of hexane was added to dissolve the pesticides and then the sample extraction solution was centrifuged at 14,000 r/min for $5 \mathrm{~min}$ at the temperature of $4^{\circ} \mathrm{C}$. Then the supernatant mixed with the internal standard solution (heptachlor epoxide) was analyzed by GC-MS.

\section{Instrumental analysis}

The total of 12 OCPs were analyzed simultaneously by GC-MS using Agilent 7890A gas chromatograph, operating in EI mode. The final sample extract was injected onto a DB-1701 capillary column $(30 \mathrm{~m} \times 0.25 \mathrm{~mm} \times 0.25 \mu \mathrm{m}$, Agilent, USA $)$ in the split mode (20:1) using helium as carrier gas at a constant flow rate of $1.2 \mathrm{~mL} / \mathrm{min}$. The temperature of the injector was $290^{\circ} \mathrm{C}$. The oven temperature was programmed to warm up from $40^{\circ} \mathrm{C}$ (holding for $1 \mathrm{~min}$ ) to $130^{\circ} \mathrm{C}$ at a rate of $30^{\circ} \mathrm{C} /$ min, then to $250^{\circ} \mathrm{C}$ at a rate of $5^{\circ} \mathrm{C} / \mathrm{min}$, and then to $300^{\circ} \mathrm{C}(5 \mathrm{~min})$ at a rate of $10^{\circ} \mathrm{C} / \mathrm{min}$. Ionization energy was $70 \mathrm{eV}$. The ion source temperature was $230^{\circ} \mathrm{C}$ and the quadruple rod temperature was $150^{\circ} \mathrm{C}$. For each chemical, the target ions were monitored for quantification (Figure 
1). The chromatogram of all the analytical contaminants was shown in Figure 1.

\section{Quality control and assurance}

The analytical method was validated and showed no interference in the retention time $\left(t_{R}\right)$ region of the test substances. The levels of quantification (LOQ) of all chemicals in the adipose tissue sample were between $2.50 \sim 19.0 \mathrm{ng} / \mathrm{g}$, with recoveries between $72.8 \% \sim 104.5 \%$. The laboratory reagent, blank samples, and spiked samples, were treated and analyzed with the same method as the actual samples. The relative standard deviation (RSD) of all the controls was between 9.65\% 16.8\%, which showed that the method was stable.

\section{Cell culture}

HepG2 cells were grown in DMEM supplemented with 10\% FBS. Cells were plated in $35 \mathrm{~mm}$ dishes and reached $\sim 70 \%$ confluence. After treated with p', p'-DDE (final concentration: $0,1,10 \mathrm{ng} / \mathrm{ml}$ ) or $\beta-\mathrm{HCH}$ (final concentration: $0,10,100 \mathrm{ng} / \mathrm{ml}$ ) for 24 hours, cells were collected. All experiments were performed in triplicates and repeated at least twice.

\section{Relative RNA expression level measurement}

Total RNA of liver tissue or HepG2 cells was extracted with Trizol (Invitrogen, Calsbad, CA) and reverse-transcribed into cDNA. Real-time quantitative PCR for hepatic genes involved in lipid metabolism was performed in triplicates using SYBR-Green (Power Master Mix Sybr Green, Applied Biosystems, Foster City, CA). All the primer sequences are available on request. Data were calculated by the delta-Ct method using cyclophilin A as the internal control.

\section{Hepatic fatty acids and cholesterol content measurement}

Hepatic fatty acids contents were measured as previously described $[33,34]$. In brief, about $20 \mathrm{mg}$ liver tissue was homogenized in ice cold PBS. Fatty acids were extracted by hexane and isopropanol. After incubated with methanol and sulfuric acid, the products, fatty acid methyl esters, were separated and identified by gas chromatography. Hepatic cholesterol concentration was assayed by gas chromatography mass spectrometry as previously reported [30].

\section{Analysis of biliary lipids composition}

Biliary cholesterol, total bile acids, and phospholipids in gallbladder bile were measured as described previously [30]. The cholesterol saturation index (CSI) was calculated using Carey's critical table [35].

\section{Western blot}

Liver homogenates or cell lysates were separated on SDS-PAGE gel and then transferred onto nitrocellulose membrane. After blocking in 5\% non-fat dry milk in PBST, the membranes were incubated overnight at $4{ }^{\circ} \mathrm{C}$ with specific primary antibody against FAS, SCD1, SREBP1c or ABCG8. After washing, secondary antibodies were incubated. The results were detected and recorded with Molecular Imager camera (Bio-Rad, Hercules, CA, USA) and densitometry analyses were performed for the quantification of results with GAPDH as a loading control.

\section{Statistical analyses}

Data analysis was performed using SAS version 9.1 (SAS Institute Inc., Cary, NC, USA). Differences in select variables between groups were evaluated using the Student $t$ test or $\chi^{2}$ test. The variables for concentrations of OCPs were evaluated using Mann-Whitney's U-test.

The OCPs concentrations were categorized into four groups, on the basis of percentile intervals $<25 \%, 25 \%$ to $<50 \%, 50 \%$ to $<75 \%$, and $\geq 75 \%$. Logistic regression was performed to obtain the odds ratio (OR) for risk of gallstone disease across the categories of OCPs, adjusting for sex, age, and BMI using the lowest category (25\%) as the reference group.

Multivariable linear regression was used to explore relationships between OCPs concentrations and biochemical index (e.g. serum concentrations of blood glucose, total cholesterol, triglyceride and et al.). Covariates considered for inclusion in the multivariate regression linear models included age, gender, and BMI. Age and BMI were modeled as continuous variables.

\section{Abbreviations}

ACC: acetyl-CoA carboxylase; ABC: ATP binding cassette; BA: bile acids; Chol: cholesterol; CSI: cholesterol saturation index; CYP7A1: cholesterol $7 \alpha$-hydroxylase, CYP8B1: cholesterol 12 $\alpha$-hydrolylase; CYP27: cholesterol 27-hydroxylase; DDE: p',p'-dichloroethylene; FA: fatty acid; FAS: fatty acid synthase; HDL: high density lipoprotein; $\mathrm{HCH}$ : $\beta$-hexachlorocyclohexane ; HMGCR: 3-hydroxy-3-methylglutaryl coenzyme A reductase; LDLR: low density lipoprotein receptor; NRs: 
nuclear receptors; OCPs: organochlorine pesticides; SCD1: stearoyl CoA desaturase 1; SREBP1c: sterol regulatory element biding protein 1c; SRB1: scavenger receptor B type 1 .

\section{CONFLICTS OF INTERESTS}

The authors have declared that no competing interests exist.

\section{GRANT SUPPORT}

This work was supported by the National Natural Science Foundation of China (Grant Nos. 81270537, $81570574,81573174,81570577)$; the Outstanding Youth Fund of Jiangsu Province (SBK2014010296); the Research Project of Chinese Ministry of Education (213015A); the Priority Academic Program Development of Jiangsu Higher Education Institutions (PAPD), the Flagship Major Development of Jiangsu Higher Education Institutions; and the Open Project Program of the State Key Laboratory of Environmental Chemistry and Ecotoxicology (KF2015-01).

\section{Author contributions}

ZYJ and AG: study concept and design; interpretation of data; statistical analysis and drafting of the manuscript; obtained funding; study supervision. GJ, $\mathrm{CX}$ and HS: acquisition of data; analysis and interpretation of data; statistical analysis and drafting of the manuscript. QL: analysis and interpretation of data and drafting of the manuscript. HH: obtaining clinical samples and drafting of the manuscript.

\section{REFERENCES}

1. Nakata H, Hirakawa Y, Kawazoe M, Nakabo T, Arizono K, Abe S, Kitano T, Shimada H, Watanabe I, Li W and Ding $\mathrm{X}$. Concentrations and compositions of organochlorine contaminants in sediments, soils, crustaceans, fishes and birds collected from Lake Tai, Hangzhou Bay and Shanghai city region, China. Environmental pollution. 2005; 133:415429.

2. Schecter A, Colacino J, Haffner D, Patel K, Opel M, Papke $\mathrm{O}$ and Birnbaum L. Perfluorinated compounds, polychlorinated biphenyls, and organochlorine pesticide contamination in composite food samples from Dallas, Texas, USA. Environmental health perspectives. 2010; 118:796-802.

3. Li QQ, Loganath A, Chong YS, Tan J and Obbard JP. Persistent organic pollutants and adverse health effects in humans. Journal of toxicology and environmental health Part A. 2006; 69:1987-2005.
4. Kiviranta H, Tuomisto JT, Tuomisto J, Tukiainen E and Vartiainen T. Polychlorinated dibenzo-p-dioxins, dibenzofurans, and biphenyls in the general population in Finland. Chemosphere. 2005; 60:854-869.

5. Dich J, Zahm SH, Hanberg A and Adami HO. Pesticides and cancer. Cancer causes \& control. 1997; 8:420-443.

6. Lee DH, Porta M, Jacobs DR, Jr. and Vandenberg LN. Chlorinated persistent organic pollutants, obesity, and type 2 diabetes. Endocrine reviews. 2014; 35:557-601.

7. Lind PM, Riserus U, Salihovic S, Bavel B and Lind L. An environmental wide association study (EWAS) approach to the metabolic syndrome. Environment international. 2013; $55: 1-8$.

8. Lee DH, Lee IK, Song K, Steffes M, Toscano W, Baker BA and Jacobs DR, Jr. A strong dose-response relation between serum concentrations of persistent organic pollutants and diabetes: results from the National Health and Examination Survey 1999-2002. Diabetes care. 2006; 29:1638-1644.

9. Rylander L, Rignell-Hydbom A and Hagmar L. A crosssectional study of the association between persistent organochlorine pollutants and diabetes. Environmental health. 2005; 4:28.

10. Lee DH, Lee IK, Jin SH, Steffes $M$ and Jacobs DR, Jr. Association between serum concentrations of persistent organic pollutants and insulin resistance among nondiabetic adults: results from the National Health and Nutrition Examination Survey 1999-2002. Diabetes care. 2007; 30:622-628.

11. Lee DH, Steffes MW, Sjodin A, Jones RS, Needham LL and Jacobs DR, Jr. Low dose organochlorine pesticides and polychlorinated biphenyls predict obesity, dyslipidemia, and insulin resistance among people free of diabetes. PloS one. $2011 ; 6: \mathrm{e} 15977$.

12. Rignell-Hydbom A, Lidfeldt J, Kiviranta H, Rantakokko P, Samsioe G, Agardh CD and Rylander L. Exposure to p,p'-DDE: a risk factor for type 2 diabetes. PloS one. 2009; 4:e7503.

13. Ha MH, Lee DH and Jacobs DR. Association between serum concentrations of persistent organic pollutants and self-reported cardiovascular disease prevalence: results from the National Health and Nutrition Examination Survey, 1999-2002. Environmental health perspectives. 2007; 115:1204-1209.

14. Kim KS, Lee YM, Kim SG, Lee IK, Lee HJ, Kim JH, Kim J, Moon HB, Jacobs DR, Jr. and Lee DH. Associations of organochlorine pesticides and polychlorinated biphenyls in visceral vs. subcutaneous adipose tissue with type 2 diabetes and insulin resistance. Chemosphere. 2014; 94:151-157.

15. Elobeid MA, Padilla MA, Brock DW, Ruden DM and Allison DB. Endocrine disruptors and obesity: an examination of selected persistent organic pollutants in the NHANES 1999-2002 data. International journal of environmental research and public health. 2010; 7:2988- 
3005.

16. Dirinck E, Jorens PG, Covaci A, Geens T, Roosens L, Neels $\mathrm{H}$, Mertens I and Van Gaal L. Obesity and persistent organic pollutants: possible obesogenic effect of organochlorine pesticides and polychlorinated biphenyls. Obesity (Silver Spring). 2011; 19:709-714.

17. Di Ciaula A, Wang DQ, Garruti G, Wang HH, Grattagliano $\mathrm{I}$, de Bari $\mathrm{O}$ and Portincasa $\mathrm{P}$. Therapeutic reflections in cholesterol homeostasis and gallstone disease: a review. Current medicinal chemistry. 2014; 21:1435-1447.

18. Di Ciaula A, Wang DQ, Wang HH, Bonfrate L and Portincasa P. Targets for current pharmacologic therapy in cholesterol gallstone disease. Gastroenterology clinics of North America. 2010; 39:245-264, viii-ix.

19. Su Y, Dai Y, Lin Y, Gao X, Han Y and Zhao B. Serum organochlorine pesticide residues and risk of gallstone disease: a case-control study in Xiamen. Annals of epidemiology. 2012; 22:592-597.

20. Wang DQ, Cohen DE and Carey MC. Biliary lipids and cholesterol gallstone disease. Journal of lipid research. 2009; 50 Suppl:S406-411.

21. Yu L, Li-Hawkins J, Hammer RE, Berge KE, Horton JD, Cohen JC and Hobbs HH. Overexpression of ABCG5 and ABCG8 promotes biliary cholesterol secretion and reduces fractional absorption of dietary cholesterol. The Journal of clinical investigation. 2002; 110:671-680.

22. Yu L, Hammer RE, Li-Hawkins J, Von Bergmann K, Lutjohann D, Cohen JC and Hobbs HH. Disruption of Abcg5 and Abcg8 in mice reveals their crucial role in biliary cholesterol secretion. Proceedings of the National Academy of Sciences of the United States of America. 2002; 99:16237-16242.

23. Horton JD and Shimomura I. Sterol regulatory elementbinding proteins: activators of cholesterol and fatty acid biosynthesis. Current opinion in lipidology. 1999; 10:143150 .

24. Zheng T, Holford TR, Mayne ST, Ward B, Carter D, Owens PH, Dubrow R, Zahm SH, Boyle P, Archibeque S and Tessari J. DDE and DDT in breast adipose tissue and risk of female breast cancer. American journal of epidemiology. 1999; 150:453-458.

25. Aronson KJ, Miller AB, Woolcott CG, Sterns EE, McCready DR, Lickley LA, Fish EB, Hiraki GY, Holloway C, Ross T, Hanna WM, SenGupta SK and Weber JP. Breast adipose tissue concentrations of polychlorinated biphenyls and other organochlorines and breast cancer risk. Cancer epidemiology, biomarkers \& prevention. 2000; 9:55-63.
26. Waliszewski SM, Aguirre AA, Infanzon RM, Silva CS and Siliceo J. Organochlorine pesticide levels in maternal adipose tissue, maternal blood serum, umbilical blood serum, and milk from inhabitants of Veracruz, Mexico. Archives of environmental contamination and toxicology. 2001; 40:432-438.

27. Covaci A, de Boer J, Ryan JJ, Voorspoels S and Schepens P. Distribution of organobrominated and organochlorinated contaminants in Belgian human adipose tissue. Environmental research. 2002; 88:210-218.

28. Ludwicki JK and Goralczyk K. Organochlorine pesticides and PCBs in human adipose tissues in Poland. Bulletin of environmental contamination and toxicology. 1994; 52:400403.

29. Wang D, Yu Y, Zhang X, Zhang D, Zhang S and Wu M. Organochlorine pesticides in fish from Taihu Lake, China, and associated human health risk assessment. Ecotoxicology and environmental safety. 2013; 98:383-389.

30. Jiang ZY, Parini P, Eggertsen G, Davis MA, Hu H, Suo GJ, Zhang SD, Rudel LL, Han TQ and Einarsson C. Increased expression of LXR alpha, ABCG5, ABCG8, and SR-BI in the liver from normolipidemic, nonobese Chinese gallstone patients. Journal of lipid research. 2008; 49:464-472.

31. Ruzzin J, Petersen R, Meugnier E, Madsen L, Lock EJ, Lillefosse H, Ma T, Pesenti S, Sonne SB, Marstrand TT, Malde MK, Du ZY, Chavey C, Fajas L, Lundebye AK, Brand CL, et al. Persistent organic pollutant exposure leads to insulin resistance syndrome. Environmental health perspectives. 2010; 118:465-471.

32. Rodriguez-Alcala LM, Sa C, Pimentel LL, Pestana D, Teixeira D, Faria A, Calhau C and Gomes A. Endocrine Disruptor DDE Associated with a High-Fat Diet Enhances the Impairment of Liver Fatty Acid Composition in Rats. Journal of agricultural and food chemistry. 2015; 63:93419348.

33. Yao X, Hou S, Zhang D, Xia H, Wang YC, Jiang J, Yin $\mathrm{H}$ and Ying $\mathrm{H}$. Regulation of fatty acid composition and lipid storage by thyroid hormone in mouse liver. Cell \& bioscience. 2014; 4:38.

34. Zong G, Ye X, Sun L, Li H, Yu Z, Hu FB, Sun Q and Lin X. Associations of erythrocyte palmitoleic acid with adipokines, inflammatory markers, and the metabolic syndrome in middle-aged and older Chinese. The American journal of clinical nutrition. 2012; 96:970-976.

35. Carey MC. Critical tables for calculating the cholesterol saturation of native bile. Journal of lipid research. 1978; 19:945-955. 